\title{
APPLICATIONS OF NANOTECHNOLOGY IN WATER TREATHENT
}

\author{
APLICAÇÕES DA NANOTECNOLOGIA \\ NO TRATAMENTO DE ÁGUA
}

\section{Aline Belem Machado linebmachado@hotmail.com}

Mestra e Doutoranda em Qualidade Ambiental pela Universidade Feevale (Novo Hamburgo/Brasil).

Gabriela Zimmermann Prado Rodrigues gabizpr@gmail.com

Mestra e Doutoranda em Qualidade Ambiental pela Universidade Feevale (Novo Hamburgo/Brasil).

\section{Luciane Rosa Feksa lucianef@feevale.br}

Doutora em Ciências Biológicas (Bioquímica) pela Universidade Federal do Rio Grande do Sul (Porto Alegre/ Brasil).

Professora na Universidade Feevale (Novo Hamburgo/Brasil).

\section{Daiane Bolzan Berlese daianeb@feevale.br}

Doutora em Bioquímica Toxicológica pela Universidade Federal de Santa Maria (Santa Maria/Brasil). Professora na Universidade Feevale (Novo Hamburgo/Brasil).

\section{José Galizia Tundisi tundisi@iie.com.br}

Doutor em Ciências Biológicas pela Universidade de São Paulo (São Paulo/ Brasil).

Professor na Universidade Feevale (Novo Hamburgo/Brasil). 


\section{ABSTRACT}

The industrial contamination, along with domestic effluents, agricultural and urban runoff are contaminating rivers and making it difficult for conventional water treatment to remove all the pollutants. This contamination can impact in the quality of rivers, in the quality of life of aquatic animals and can impact in the human health through the consumption of water. In order to improve the water quality, nanotechnology has been studied as an alternative to better remove contaminants, such as, heavy metals, oily water separation and antimicrobial activity. Besides, with the increase in industrialization along with the contamination of rivers, seawater could be an interesting alternative for drinking water source after adequate treatment. Nanomaterials are being studied as a possibility to remove salt from seawater, making it possible to drink. Howerver, there is a need to elucidate the potential risks to the environemt that these nanomaterials can cause. Therefore, the aim of this review is to describe some applications of nanotechnology in water treatment regarding metals, oil removal from water, antimicrobial activity and desalination in order to improve water quality, as well, as discuss their potential risk to the environment. Keywords: Antimicrobial activity. Environmental risks. Nanotechnology. Pollutants. Water contamination.

\section{RESUMO}

A contaminação industrial, juntamente com efluentes domésticos, agricultura e escoamento urbano, estão contaminando os rios e dificultando para os tratamentos de água convencionais removerem todos os poluentes. Esta contaminação pode impactar na qualidade dos rios, na qualidade de vida dos animais marinhos e pode impactar na saúde humana através do consumo de água. Com a finalidade de melhorar a qualidade da água, a nanotecnologia tem sido estudada como uma alternativa para melhor remover os poluentes, como, metais pesados, separar óleo da água e atividade antimicrobiana. Além disso, com o aumento da industrialização juntamente com a contaminação dos rios, a água do mar poderia ser uma alternativa interessante como fonte de água potável após o tratamento adequado. Nanomateriais estão sendo estudado como uma possibilidade para remover o sal da água do mar, tornando-a possível de ser ingerida. Entretanto, há a necessidade de elucidar os potenciais riscos para o meio ambiente que estes nanomateriais podem causar. Sendo assim, o objetivo deste artigo de revisão é descrever algumas aplicações da nanotecnologia no tratamento de água em relação à remoção de metais e óleo da água, atividade antimicrobiana e a dessalinização a fim de melhorar a qualidade da água, assim como, discutir os potenciais riscos para o meio ambiente.

Palavras-chave: Atividade antimicrobiana. Contaminação da água. Nanotecnologia. Poluentes. Riscos ambientais. 


\section{INTRODUCTION}

The growth in industrialization has consequently polluted rivers through the discharge of hazardous chemicals, including heavy metals, into the environment (ISLAM et al., 2015; RASTMANESH et al., 2018). Along with the industrial contamination, domestic effluents, agricultural and urban runoffs are of concern to the quality of the rivers (DALZOCHIO et al., 2018). This contamination may result in the bioaccumulation of metals in water and aquatic animals (RASTMANESH et al., 2018), being a threat to human and animal health (DALZOCHIO et al., 2018). Aquatic contaminants such as heavy metal ions and dyes are very harmful to living beings and can affect the ecosystem (SANTHOSH et al., 2016).

Conventional water treatments are no longer efficient to remove many of the pollutants found in water in order to achieve water quality standards. They often rely on centralized systems, which the distribution and discharge processes are not sustainable for nowadays' needs (QU et al., 2013). Based on this problem, nanotechnology could improve water treatment because of the size of nanomaterials, in which the surface area is bigger, improving the contact with water; high reactivity; fast kinetics; specificity to contaminants and, another important advantage is the cost of nanomaterials that are decreasing (ZHANG et al., 2016).

It is estimated that approximately 663 million people doesn't have access to potable water, mainly in developing countries (WHO/ UNICEF, 2015). So, it becomes necessary to provide basic water treatment to these people, where water treatment sometimes is non-existent (QU et al., 2013). The removal of pollutants from contaminated water is necessary to prevent damages to human health and to the environment (SANTHOSH et al., 2016). Based on the problems abovementioned, the present review aimed on the application of nanomaterials to improve the quality of water regarding the metals and oil removal, desalination capacity and antimicrobial activity, as well as, discuss the potential risks that these nanomaterails can cause to the environment.

\section{METHODS}

The present review was undertaken based on the research of manuscripts about nanotechnology and its applications in water treatment regarding the efficiency in metal removal, separation of oil from oily water, antimicrobial activity and the potential risks of nanomaterials to the environment. These manuscripts were searched in Science Direct, Scopus, PubMed, and Periódicos Capes database. 


\section{NANOTECHNOLOGY}

Nanoscience studies the phenomena on a nanometer scale (CHATURVEDI et al., 2012). Nanotechnology involves nanomaterials that have at least one component with one dimension less than $100 \mathrm{~nm}$ (TEOW; MOHAMMAD, 2017). Nanotechnology had its beginning in 1959 with the lecture entitled "There's plenty of room at the bottom" given by the physicist Richard Feynman at the annual American Physical Society meeting (SAVOLAINEN et al., 2010). Nanotechnology has been studied for wastewater treatment and has been cited as one of the most advanced process in this field. Based on the nanomaterial, the water treatment can be divided into three main groups: nano-adsorbents, nanocatalysts and nano-membrane (ANJUM et al., 2016).

- Nano-adsorbents are nanoparticles made of organic or inorganic materials with a high affinity to adsorb substances (SANTHOSH et al., 2016), in another words, they have a capability to remove many pollutants. These nanoparticles are developed and used to remove different types of contaminants. This kind of material have important characteristics, such as, catalytic potential, small size, high reactivity, and large surface energy (BASHEER et al., 2018). They can be classified based on their adsorption process, which includes metallic nanoparticle, nanostructured mixed oxides, magnetic nanoparticles and metallic oxide nanoparticles (ANJUM et al., 2016).

- Nano-catalysts are based on the interaction of light energy with metallic nanoparticles. This treatment is becoming of great interest due to the high and broad photocatalytic activities (AKHAVAN, 2009). Photocatalytc activities are based on the destruction of bacteria and organic substances by the reaction with hydroxyl radicals (KHAYDAROV etal., 2013). The materials used in nano-catalysts usually are inorganic materials such as semiconductors and metal oxides (ANJUM et al., 2016). However, to be considered a nano-photocatalytic, they must follow some requirements: to be harmless and have their concentration in the water and air lower than the maximum permissible value; to form agglomerates, coagulate and precipitate; and to form safe ordinary particles (KHAYDAROV et al., 2013).

- Nano-membranes are responsible for the separation of particles from the wastewater (ANJUM et al., 2016). They can be very efficient in the removal of dyes, heavy metals, and other contaminants (JIE et al., 2015). The nanomaterials used as nano-membranes are nanotubes, nanoribbons, and nanofibers (LIU et al., 2014).

Conventional water treatment sometimes cannot be very effective in removing some contaminants, such as, metals and microorganisms (ADELEYE et al., 2016). Another problem is the formation of disinfection byproducts (DPBs), which are dangerous to human health (LI et al., 2008). These DPBs are 
the result of the reaction of chemical disinfectants with organic matters and inorganic ion present in the water (CORTÉS; MARCOS, 2018), which are added to the wastewater secondary effluent in order to prevent biofouling (XU et al., 2018). Antimicrobial nanomaterials, for example, usually do not produce these DPBs because they are not strong oxidants, so they can be important decontaminants, improving the water treatment (LI et al., 2008).

The access to potable water is an important factor to avoid people from getting ill. Waterborne diseases are the lead cause of death worldwide, mainly in developing countries. Diarrhea, a consequence of this situation, kills approximately 2.2 million people every year, specially affecting children under 5 years old (LI et al., 2008). If no potable water is available for drinking purposes, many sanitary problems can occur and lead to health and economic problems (HATAMIE et al., 2016).

Some studies have been evaluating the capability of nanomaterials to remove contaminants from water. Nanomaterials have been studied as an alternative to remove metals, microorganisms and oil from contaminated water. Also, nanomaterials were developed to desalinate water as a possibility to use seawater as a drinking source. Some examples of these applications are described below.

\subsection{METALS REMOVAL}

Heavy metals as well as some anions present high toxicity and this property can cause real damages to humans and ecossystems (HATAMIE et al., 2016). Based on that, Hatamie and collaborators (2016) studied the efficacy of magnetic nano-ferrofluid, which acts as a coagulant in the water, as a possible absorbent of heavy metals. The results demonstrated that the metal removal efficiency increased to almost $100 \%$ when the $\mathrm{pH}$ was also increased from 4 to 8 , these heavy metals were $\mathrm{Fe}^{2+}, \mathrm{Pb}^{2+}, \mathrm{Zn}^{2+}$ and $\mathrm{Cu}^{2+}$. The other metals analyzed $\left(\mathrm{Ni}^{2+}, \mathrm{Mn}^{2+}, \mathrm{Co}^{2+}, \mathrm{Cd}^{2+}\right)$ also had an increase in the metal removal efficiency, however they remain lower that $90 \%$.

Some methodologies are used to remove heavy metals from water such as ion exchange, chemical precipitation, membrane filtration, coagulation, biological or electrochemical remediation and adsorption (VILARDI et al., 2018). Among these processes, adsorption demonstrated to be more flexible in design and operation, and can generate treated water with high-quality (HUA et al., 2012).

Nanosized metal oxides are important adsorbents which includes iron oxides, manganese oxides, aluminum oxides, and titanium oxides. The size and shape of these materials are important factors to the adsorption performance (HUA et al., 2012). The use of iron oxides nanomaterials in water treatment can occur from two different applications: (i) using iron nanomaterial as a kind of nanoadsorbent and, (ii) using as a photocatalysts, converting the contaminants to less toxic substances (XU et al., 2012). 
Carbon based materials are being used as adsorbents, one example is carbon nanotubes (CNT), they have high surface area to volume ratio and pore size distribution. With these characteristics the CNT presents important sorption capability in comparison to granular or powder activated carbon. Another carbon based material is graphene, they are considered efficient adsorbents because of their large specific area and electron rich environment. Graphene oxide also demonstrated to have high adsorbent capacity due to their strong functional groups (SANTHOSH et al., 2016).

\subsection{OIL REMOVAL}

Oil is an important energy source in the world, however, when it is explored, transported or stored there is a risk of spillage (SYED et al., 2011). Spill accidents involving oil has occurred from natural sources or disposal disaster from industries and consequently it has been impacting the ecosystem (TAN et al., 2015). Along with industries, domestic effluents can also contain oil and their use are increasing fast (LU; YUAN, 2018).

Different methodologies are applied to separate oil from an oil-contaminated water, nevertheless they are expensive and sometimes not very effective (VELAYI; NOROUZBEIGI, 2018). New technologies have been studied for this purpose and nanotechnology demonstrated to be more cost-effective so far (SYED et al., 2011). Some nanomaterials properties can become interesting in separating oil from water effectively, which includes, high separation efficiency, good recyclability, environmental friendliness and easy fabrication (LU; YUAN, 2018).

Some researchers developed structures with nanomaterials to separate oil from water. A research performed by Syed and collaborators (2011) used hydrophobic nano-silica to remove gasoline and diesel from water. Their results demonstrated that this material was more effective in removing these oils when compared to organic or inorganic adsorbents available in literature data.

Tan etal.(2015) evaluated the possibility of different structures of titanium dioxide $\left(\mathrm{TiO}_{2}\right)$ nanoparticles (nanowire, nanotube, and nanosheet) to perform as a filter. They developed nanostructures membranes that had superhydrophilic and underwater superoleophobic characteristics. The results demonstrated that the nanosheet of $\mathrm{TiO}_{2}$ had the best capability of separation of oil from oil-contaminated water.

Lu and Yuan (2018) developed a sponge capable of removing oil from the water. They utilized silver nanoparticles coated on the surface of a porous sponge. The results showed that it had superhydrophobicity and self-cleaning properties and that the sponge could be reutilized for several times. However, from the many organic solvents and oils tested, the absorption capacity of the sponge was dependent on the density, viscosity and surface tension of the materials, which resulted in different volumes absorption capacity. 


\subsection{DESALINATION}

The population growth and urbanization will eventually require for new accessible fresh water supply, and the desalination is being studied as an important source of drinking water, once seawater represents a huge supply of water (SURWADE et al., 2015). Desalination in characterized by the extraction of mineral components from different sources of water, such as, sea water, brackish water and treated water. Some conventional methods are known to remove salt from water, these processes include precipitation, oxidation, reduction, ion exchange, membrane filtration and adsorption (ZAHED et al., 2018).

Conventional water treatment is not very effective in removing salt from water (TEOW \& MOHAMMAD, 2017), however, some methodologies such as reverse osmoses membranes require high pressures and results in substantial quantities of liquid wastes. Therefore, the utilization of nanomaterials that require less pressure as well as low energy consumption and high salt rejection are being studied as a viable route for sustainable membrane desalination (GOH et al., 2016).

One nanomaterial that is of great interest is graphene, an allotrope of carbon and, because of its properties such as strength, chemical and thickness, it became more studied. Researches performed with graphene demonstrated the potential that nanoporous graphene can have as a selective membrane for water desalination (SURWADE et al., 2015). Graphene oxide (GO), a form of graphene, contains functional groups that results in a hydrophilicity and high negative charge density, and these characteristics are essential to the desalination process (ZAHED et al., 2018).

Another research, conducted by Abo-Almaged and Gaber (2017), evaluated the ability of nanohydroxyapatite membranes to reject salt from water. The results demonstrated that when the $\mathrm{NaCl}$ concentration increased, the salt rejection by the membrane increased as well, reaching a rejection of $73 \%$ to a 5000 ppm concentration of salt.

\subsection{ANTIMICROBIAL ACTIVITY}

According to the Guidelines for Drinking-Water Quality (World Health Organization, 2017), pathogenic bacteria, viruses and parasites can cause infectious diseases which are the most common and widespread health risks associated with drinking-water.

Khaydarov and collaborators (2013) synthesized nanocarbon-titanium with functional groups on the surface of carbon nanoparticles with nano-photocatalysts properties. They evaluated the antimicrobial activity on Escherichia coli in water under sunlight irradiation at 11 am during 6 hours. The results demonstrated that the water disinfection is time dependent on the bacteria concentration (around 1 hour), it was successfully capable of destructing the bacteria. 
Another example of antimicrobial activity using nanotechnology is the research accomplished by Pina and collaborators (2014) that developed a poly(ethylene) glycol (PEG)-coated magnetic nanoparticles, functionalized with $(\mathrm{RW})_{3}$ (an antimicrobial peptide) to act as an antimicrobial against E. coli and Bacillus subtilis. These magnetic nanoparticles are widely used in different contaminants, such as, metals removal, detection of bacteria, parasites, viruses, or antibiotic and in the separation of pollutants. Nevertheless, these magnetic nanoparticles can be functionalized with molecules that can interact or destruct bacteria. The results showed that the nanoparticle was able to disinfect the water, decreasing significantly both bacterial populations (E. coli and B. subtilis).

Carbon nanotubes have been demonstrating to have interesting results when evaluating the removal or even inactivation of pathogenic bacteria and viruses from water. Based on this statements, Parham and collaborators (2013) developed carbon nanotubes that grew in the open pores of a porous ceramic matrix. They tested the capability of this filter to remove microorganism from water, they utilized Saccharomyces cerevisiae as a model. After the filtration, some procedures were carried out to analyze the efficiency of the filter. The results showed that the filter had the yeast attached to the carbon nanotubes network. They also analyzed the influence of the filter length and aqueous flow, which demonstrated to have a strong effect on the efficiency of the yeast filtration. The filter length of 50 and $70 \mathrm{~mm}$ with an aqueous flow of $20 \mathrm{~mL} / \mathrm{h}$ demonstrated an efficiency of $98 \%$ yeast filtration.

\section{POTENTIAL RISKS TO THE ENUIRONMENT}

Although nanotechnology has proven to be very effective in different areas by improving the environmental quality, some aspects need to be discussed whether nanomaterials and/or nanoparticles can affect the environment and the aquatic biota. However, giving the increasing progress in nanotechnology, there isn't enough information about the effects on human health. Another issue is that nanomaterials cannot be yet detected in the environment and, this can result in different types of environmental problems (KABIR et al., 2018).

There are many different sources of nanomaterials in the environment, they include intentional releases and unintentional releases which can occur from atmospheric emissions and solid or liquid waste streams from production services (KLAINE et al., 2008). Some aspects influence the effect of nanomaterials in the environment, such as, concentration, presence of organic or inorganic materials, $\mathrm{pH}$. Also, the period that the particle remains in the ecosystems reflects in its toxicity, the longer the period, the more toxic it becomes (PUROHIT et al., 2017). For example, if photosynthetic microorganisms, base of 
many trophic chains, are exposed to nanomaterials, many severe effects could occur on the whole trophic chain (MOTTIER et al., 2017).

A literature review was performed by Naasz and collaborators (2018) in order to analyze publications regarding the evaluation of ecotoxicology effects in organisms (cell line, bacteria, algae, crustaceans, fish, mollusks, nematodes and plants) exposed to mixtures of nanomaterials and chemicals. From their research, 151 publications were found concerning these topics, $\mathrm{TiO}_{2}$ was the nanomaterial with more publications in relation to exposure and, crustaceans were the most used organism tested. From the 151 publications, 127 studies (66\%) reported that mixture exposure increased the toxicity comparing to single-substance exposure. And the remaining studies (26) stated a decrease in the toxicity when the organisms were exposed to mixture of chemicals.

An important key role to determine the effects that nanomaterials can cause to organisms is the knowledge of the main sources, pathways, transformations, and sinks of the nanomaterials, providing information about the areas, such as, water, sediment, and biota, that will suffer from this exposure (LEAD et al., 2018). In conclusion, besides nanotechnology can provide innumerous improvements in water treatment, it can also be causing damages to organisms exposed to nanomaterials and/or nanoparticles, however, many new researches need to be carried out in order to provide more conclusions about their potential risks to the environment.

\section{5 conclusions}

In the present review, some nanomaterials were described for their application in water treatment. Conventional water treatment sometimes is not very effective in removing some pollutants, such as, heavy metals, oil and microorganism. To improve this treatment, nanomaterials are being studied as a possible alternative to remove these contaminants. Also, with the growth of urbanization and industrialization with consequent water contamination, in the future it will be necessary to use another source as drinking water. One possibility is seawater, and the desalination performed by nanomaterials is an interesting alternative to remove salt from water. However, since nanotechnology is considered new, its effects cannot be all predicted, so many reaserches need to be performed aiming in its potential risks to the environemnt and biota. In conclusion, many nanomaterials have been demonstrating their effectiveness in removing contaminants from water, being a possible alternative for water treatment in the future. 


\section{REFERENCES}

ABO-ALMAGED, H. H.; GABER, A. A. Synthesis and characterization of nano-hydroxyapatite membranes for water desalination. Materials Today Communications, England, v. 13, p. 186-191, oct. 2017.

ADELEYE, A. S.; CONWAY, J. R.; GARNER, K.; HUANG, Y.; SU, Y.; KELLER, A. A. Engineered nanomaterials for water treatment and remediation: costs, benefits, and applicability. Chemical Engineering Journal, Switzerland, v. 286, p. 640-662, nov. 2016.

AKHAVAN, O. Lasting antibacterial activities of $\mathrm{Ag}-\mathrm{TiO} 2 / \mathrm{Ag} / \mathrm{a}-\mathrm{TiO} 2$ nanocomposite thin film photocatalysts under solar light irradiation. Journal of Colloid and Interface Science, United States, v. 336, n. 1, p. 117-124, aug. 2009.

ANJUM, M.; MIANDAD, R.; WAQAS, M.; GEHANY, F.; BARAKAT, M. A. Remediation of wastewater using various nano-materials. Arabian Journal of Chemistry, Saudi Arabia, oct. 2016.

BASHEER, A. A. New generation nano-adsorbents for the removal of emerging contaminants in water. Journal of Molecular Liquids, Netherlands, v. 261, p. 583-593, apr. 2018.

CORTÉS, C.; MARCOS, R. Genotoxicity of disinfection byproducts and disinfected waters: A review of recent literature. Mutation Research/Genetic Toxicology and Environmental Mutagenesis, Netherlands, v. 831, p. 1-12, jul. 2018.

DALZOCHIO, T.; RODRIGUES, G. Z. P. , SIMÕES, L. A. R.; SOUZA, M. S., PETRY, I. E.; ANDRIGUETTI, N. B.; SILVA, G. J. H.; SILVA, L. B; GEHLEN, G. In situ monitoring of the Sinos River, southern Brazil: water quality parameters, biomarkers, and metal bioaccumulation in fish. Environmental Science and Pollution Research, Germany, v. 25, n. 10, apr. 2018.

GOH, P. S.; ISMAIL, A. F.; HILAL, N. Nano-enabled membranes technology: Sustainable and revolutionary solutions for membrane desalination?. Desalination, Netherlands, v. 380, p. 100-104, feb. 2016.

HATAMIE, A.; PARHAM, H.; ZARGAR, B.; HEIDARI, Z. Evaluating magnetic nano-ferrofluid as a novel coagulant for surface water treatment. Journal of Molecular Liquids, Netherlands, v. 219, p. 694-702, apr. 2016.

HUA, M.; ZHANG, S.; PAN, B.; ZHANG, W.; LV, L.; ZHANG, Q. Heavy metal removal from water/ wastewater by nanosized metal oxides: a review. Journal of Hazardous Materials, Netherlands, v. 211, p. 317-331, apr. 2012. 
ISLAM, M. S.; AHMED, K.; RAKNUZZAMAN, M.; AL-HAMUN, H.; ISLAM, M. K. Heavy metal pollution in surface water and sediment: a preliminary assessment of an urban river in a developing country. Ecological Indicators, United States, v. 48, p. 282-291, jan. 2015.

JIE, G.; KONGYIN, Z.; XINXIN, Z.; ZHIJIAN, C.; MIN, C.; TIAN, C.; JUNFU, W. Preparation and characterization of carboxyl multi-walled carbon nanotubes/calcium alginate composite hydrogel nano-filtration membrane. Materials Letters, Netherlands, v. 157, p. 112-115, may. 2015.

KABIR, E.; KUMAR, V.; KIM, K.-H.; YIP, A. C. K.; SOHN, J. R. Environmental impacts of nanomaterials. Journal of Environmental Management, England, v. 225, p. 261-271, aug. 2018.

KHAYDAROV, R. A.; KHAYDAROV, R. R.; GAPUROVA, O. Nano-photocatalysts for the destruction of chloro-organic compounds and bacteria in water. Journal of Colloid and Interface Science, United States, v. 406, p. 105-110, jun. 2013.

KLAINE, S. J.; ALVAREZ, P. J. J.; BATLEY, G. E.; FERNANDES, T. F.; HANDY, R. D.; LYON, D. Y.; MAHENDRA, S. Y.; MCLAUGHLIN, M. J.; LEAD, J. R. Nanomaterials in the environment: behavior, fate, bioavailability, and effects. Environmental Toxicology and Chemistry, Unites States, v. 27, n. 9, p. 1825-1851, nov. 2008.

LEAD, J. R.; BATLEY, G. E.; ALVAREZ, P. J. J.; CROTEAU, M.-N.; HANDY, R. D.; MCLAUGHLIN, M. J.; JUDY, J. D.; SCHIRMER, K. Nanomaterials in the Environment: Behavior, Fate, Bioavailability, and Effects - An Updated Review. Environmental Toxicology and Chemistry, United States, v. 37, n. 8, p. 2019-2063, mar. 2018.

LI, Q.; MAHENDRA, S.; LYON, D. Y.; BRUNET, L.; LIGA, M. V.; LI, D.; ALVAREZ, P. J. J. Antimicrobial nanomaterials for water disinfection and microbial control: potential applications and implications.

Water Research, England, v. 42, n. 18, p. 4591-4602, aug. 2008.

LU, Y.; YUAN, W. Superhydrophobic three-dimensional porous ethyl cellulose absorbent with micro/ nano-scale hierarchical structures for highly efficient removal of oily contaminants from water.

Carbohydrate Polymers, v. 191, p. 86-94, mar. 2018.

MOTTIER, A.; MOUCHET, F.; PINELLI, É.; GAUTHIER, L.; FLAHAUT, E. Environmental impact of engineered carbon nanoparticles: from releases to effects on the aquatic biota. Current Opinion in Biotechnology, England, v. 46, p. 1-6, jan. 2017. 
NAASZ, S.; ALTENBURGER, R.; KÜHNEL, D. Environmental mixtures of nanomaterials and chemicals: The Trojan-horse phenomenon and its relevance for ecotoxicity. Science of the Total Environment, Netherlands, v. 635, p. 1170-1181, apr. 2018.

PARHAM, H.; BATES, S.; XIA, Y.; ZHU, Y. A highly efficient and versatile carbon nanotube/ceramic composite filter. Carbon, v. 54, p. 215-223, nov. 2013.

PINA, A. S.; BATALHA, I. L.; FERNANDES, C. S. M.; AOKI, M. A.; ROQUE, A. C. A. Exploring the potential of magnetic antimicrobial agents for water disinfection. Water Research, England, v. 66, p. 160-168, aug. 2014.

PUROHIT, R.; MITTAL, A.; DALELA, S.; WARUDKAR, V.; PUROHIT, K.; PUROHIT, S. Social, Environmental and Ethical Impacts of Nanotechnology. Materials Today: Proceedings, England, v. 4, n. 4, p. 54615467, 2017.

QU, X.; ALVAREZ, P. J. J.; LI, Q. Applications of nanotechnology in water and wastewater treatment. Water Research, England, v. 47, n. 12, p. 3931-3946, aug. 2013.

QU, X.; BRAME, J.; LI, Q.; ALVAREZ, P. J. Nanotechnology for a safe and sustainable water supply: enabling integrated water treatment and reuse. Accounts of Chemical Research, United States, v. 46, n. 3, p. 834-843, jun. 2013.

RASTMANESH, F.; SAFAIE, S.; ZARASVANDI, A. R.; EDRAKI, M. Heavy metal enrichment and ecological risk assessment of surface sediments in Khorramabad River, West Iran. Environmental Monitoring and Assessment, Netherlands, v. 190, n. 5, p. 273, apr. 2018.

SANTHOSH, C.; VELMURUGAN, V.; JACOB, G.; JEONG, S. K.; GRACE, A. N.; BHATNAGAR, A. Role of nanomaterials in water treatment applications: a review. Chemical Engineering Journal, Switzerland, v. 306, p. 1116-1137, dec. 2016.

SAVOLAINEN, K.; ALENIUS, H.; NORPPA, H.; PYLKKÄNEN, L.; TUOMI, T.; KASPER, G. Risk assessment of engineered nanomaterials and nanotechnologies-a review. Toxicology, Ireland, v. 269, n. 2-3, p. 92104, mar. 2010.

SURWADE, S. P. ; SMIRNOV, S. N.; VLASSIOUK, I. V.; UNOCIC, R. R.; VEITH, G. M.; DAI, S.; MAHURIN, S. M. Water desalination using nanoporous single-layer graphene. Nature Nanotechnology, England, v. 10, n. 5, p. 459-464, mar. 2015. 
SYED, S.; ALHAZZAA, M. I.; ASIF, M. Treatment of oily water using hydrophobic nano-silica. Chemical Engineering Journal, Switzerland, v. 167, n. 1, p. 99-103, feb. 2011.

TAN, B. Y. L.; TAI, M. H.; JUAY, J.; LIU, Z.; SUN, D. A study on the performance of self-cleaning oil-water separation membrane formed by various $\mathrm{TiO}_{2}$ nanostructures. Separation and Purification Technology, Netherlands, v. 156, p. 942-951, dec. 2015.

VELAYI, E.; NOROUZBEIGI, R. Synthesis of hierarchical superhydrophobic zinc oxide nano-structures for oil/water separation. Ceramics International. England, v. 44, n. 12, p. 14202-14208, aug. 2018.

VILARDI, G.; MPOURAS, T.; DERMATAS, D.; VERDONE, N.; POLYDERA, A.; DI PALMA, L. 2018.

Nanomaterials application for heavy metals recovery from polluted water: The combination of nano zero-valent iron and carbon nanotubes. Competitive adsorption non-linear modeling. Chemosphere, England, v. 201, p. 716-729, jun. 2018.

WHO, World Health Organization. Guidelines for drinking-water quality: fourth edition incorporating the first addendum. WHO, 2017. Available at: <http://apps.who. int/iris/bitstream/handle/10665/254637/9789241549950-eng.pdf;jsessionid= F243D62FDA2E4C2CA246F8B3463955DB?sequence=1>. Accessed on: 07 oct. 2018.

WHO/UNICEF, World Health Organization/UNICEF. Progress on sanitation and drinking water - 2015 update and MDG assessment. Geneva, WHO, 2015. Available at: <http://files.unicef.org/publications/ files/Progress_on_Sanitation_and_Drinking_Water_2015_Update_.pdf>. Accessed on: 23 jul. 2018.

XU, J.; TRAN, T. N.; LIN, H.; DAI, N. Removal of disinfection byproducts in forward osmosis for wastewater recycling. Journal of Membrane Science, Netherlands, v. 564, p. 352-360, oct. 2018.

XU, P. ; ZENG, G. M.; HUANG, D. L.; FENG, C. L.; HU, S.; ZHAO, M. H.; LAI, C.; WEI, Z.; HUANG, C.; XIE, G. $X . ;$ LIU, Z. F. Use of iron oxide nanomaterials in wastewater treatment: a review. Science of the Total Environment, Netherlands, v. 424, p. 1-10, may. 2012.

ZAHED, M.; PARSAMEHR, P. S.; TOFIGHY, M. A.; MOHAMMADI, T. Synthesis and functionalization of graphene oxide (GO) for salty water desalination as adsorbent. Chemical Engineering Research and Design, v. 138, p. 358-365, 2018.

ZHANG, Y.; WU, B.; XU, H.; LIU, H.; WANG, M.; HE, Y.; PAN, B. Nanomaterials-enabled water and wastewater treatment. Nanolmpact, Netherlands, v. 3, p. 22-39, jul. 2016. 